\title{
What is the evidence linking financial assistance for drought-affected agriculture and resilience in tropical Asia? A systematic review
}

\author{
Daniel Goodwin ${ }^{1}$ lan Holman ${ }^{1} \cdot$ Liwa Pardthaisong $^{2}$ - Supattra Visessri ${ }^{3}$. Chaiwat Ekkawatpanit ${ }^{4}$. \\ Dolores Rey Vicario ${ }^{1}$
}

Received: 1 October 2021 / Accepted: 15 December 2021 / Published online: 17 January 2022

(c) The Author(s) 2021

\begin{abstract}
Agriculture is sensitive to drought and associated social, environmental and economic impacts. Finance-based interventions aim to support farmers affected by drought; however, the extent to which such tools encourage resilience to this natural hazard is unclear. This paper systematically reviews evidence on links between financial interventions to mitigate droughtrelated impacts and adaptation towards longer-term resilience. We focus on tropical Asia where agriculture contributes significantly to national economies and is a primary source of livelihood in a region subject to high climate variability and episodic drought. Guided by Population, Intervention, Comparator and Outcome criteria, we identify and review 43 regionally specific articles that describe a range of financial interventions. Through thematic synthesis, we document the interventions' associations with micro-level and macro-level outcomes. The results reveal how some interventions helped sustain household incomes and crop yield (e.g. through farm investments that increased productivity) through drought, whilst others encouraged adaptive behaviours. At a macro-level, there were challenges associated with government budgets and scheme administration, with the longevity of many schemes difficult to sustain. From fragmented evidence, this review reasons that there can be challenging policy trade-offs for institutions between supporting livelihoods and economic growth whilst also protecting the environment - highlighting the interdependence of systems' resilience and variability in actors' capacity to adapt. Low-regret interventions that integrate existing community adaptive practices, engage with farmers' needs and prioritise extension support may encourage more desirable counteractions to drought; however, further research is needed to establish the role of such interventions.
\end{abstract}

Keywords Drought risk management $\cdot$ Financial compensation $\cdot$ Vulnerability $\cdot$ Adaptive capacity $\cdot$ Crop insurance

\section{Introduction}

Communicated by Jamie Pittock

Ian Holman

i.holman@cranfield.ac.uk

1 Cranfield Water Science Institute, Cranfield University, Bedfordshire MK43 0AL, UK

2 Department of Geography, Faculty of Social Sciences, Chiang Mai University, Chiang Mai, Thailand

3 Department of Water Resources Engineering, Faculty of Engineering, Chulalongkorn University, Bangkok, Thailand

4 Department of Civil Engineering, King Mongkut's University of Technology, Bangkok, Thailand
Agriculture in tropical Asia is sensitive to drought and the associated social, environmental and economic impacts (Franzetti et al. 2017). Countries in the region regularly experience episodic dry season droughts (Pavelic et al. 2012) due to inadequate pre-monsoon rainfall, a delay in the onset of the rainy season or its early departure (Habiba et al. 2014). Formal institutions, such as governments, respond to the economic risks of drought (and other climate and nonclimate conditions) through a range of financial mechanisms (Smit and Skinner, 2002). At a policy level, governments may select from a variety of strategies that aim to manage the risks associated with climate variability and change (Aakre et al. 2010), that help to smooth farm incomes, and include publicly funded input subsidies, compensation for harvest losses, minimum price support systems, 
public-private insurance schemes or low-interest loans (Prasada, 2020; Ghosh et al. 2021). Multiple agencies may have to coordinate decisions during dry periods relating to the declaration of a disaster and how and when to distribute financial support (Stricevic et al. 2011). Ultimately, the risk may be distributed in different ways across levels of government, private industry (insurers) and farmers (Pasaribu and Sudiyanto, 2016) and, in some international settings, the policy shift has been towards farmer self-reliance, particularly through insurance and preparedness (Wilhite et al. 2000), with government assistance only available in more exceptional circumstances (Wright, 2005).

Post-disaster financial relief may disincentivise longerterm adaptation, particularly where the recovery does not address existing vulnerabilities, does not reach those that are most vulnerable or focuses resources too heavily on short-terms needs (Cutter et al. 2012; Wilhite et al. 2013). In recent years, countries in Asia and the Pacific, a region dominated by middle-income countries where agriculture is a major economic sector and a critical source of livelihood (Mia et al. 2015), have allocated significant funds to disaster risk financing (IRGP and MSC, 2019). Regional reviews on drought resilience (SAARC, 2010; UNESCAP and ASEAN, 2020) recommend exploring financing measures that can reallocate risk and shift towards more ex ante financial instruments for drought risk management and climate change adaptation. In this regard, considerable attention has been paid to crop insurance schemes, including weather index and revenue-based policies, that aim to protect farmers against crop and income losses (Sinha and Tripathi, 2016). Current scholarly interest centres around understanding whether certain financial interventions designed to support agricultural sectors during drought function better than others (Ricome et al. 2017) and the advantages and disadvantages of providing support ex ante or ex post (Linnerooth-Bayer and Hochrainer-Stigler, 2015; Guimarães Nobre et al. 2019).

Underpinning this study is a comparatively limited evidence base describing the impacts of financial relief on facilitating adaptations to the drought that can help build agricultural resilience in tropical Asia. Adaptation can occur at both the farm scale and at national or regional scales; thus, evaluation of financial interventions should consider both microand macro-level responses (Kandlikar and Risbey, 2000; Bradshaw et al. 2004; Habiba et al. 2014; Mia et al. 2015) to help understand where to target interventions (Williams and Carrico, 2017) and the inter-relationship between policy and farmers' actions (Singh et al. 2018). At the micro-level, farmers may adapt through changing crop varieties, planting dates or fertilisers (Abid et al. 2015), improving irrigation efficiency (Swain, 2014) or investing to increase water supply (Bastakoti et al. 2014). In lieu of more sustained adaptive adjustments, farmers may resort to shorter-term coping by drawing down savings, borrowing or migrating for work
(Smit and Skinner, 2002; Field et al. 2012; Shaffril et al. 2018). At a macro-level, the financial intervention may be associated with policy, management and strategy refinement (Sinha and Tripathi, 2016; Suebpongsang et al. 2020); modified institutional arrangements (Smit and Skinner, 2002) or modified governance practices (Hurlbert and Gupta, 2019). Moreover, at the macro-level, the intervention may contribute to wider social, economic and environmental impacts (Reidsma et al. 2010). Across these levels, the outcomes of intervention can serve as indicators of adaptive capacity or resilience in different contexts (Reidsma et al. 2010). For example, a resilient system will continue to provide income for farmers, support crop yields, sustain communities and the economy, even when challenged by drought (Lin, 2011) whilst adaptability refers to the capacity of actors in the system to manage and influence resilience (Engle, 2011) and to (intentionally) reorganise, change and learn in response to the threat of drought (Cutter et al. 2008; Carter et al. 2018).

This systematic review (SR) aims to synthesise and critically examine existing evidence around the advantages and disadvantages of institutional financial responses to drought and the associations with adaptation and resilience in tropical Asia. Guided by research that draws together farm and regional level factors (Reidsma et al. 2010), adaptability as a characteristic of a resilient farming system (Meuwissen et al. 2019) and depictions of conceptual links between vulnerability, adaptive capacity and resilience (see Cutter et al. 2008; Engle, 2011), we ask (i) what are the micro and macro-level outcomes associated with financial interventions designed to support drought management in tropical Asia and in what way do the interventions influence the outcomes? and (ii) to what extent might the different financial interventions affect drought adaptation and resilience of agricultural systems in tropical Asia? The study contributes to the understanding of the form and function (including timing) of financial interventions and to how the link between institutional responses to drought and agricultural adaptations and resilience might be strengthened. This review ultimately aims to help support policymakers, academics, industry and farmers understand how financial interventions can help strengthen agricultural resilience in tropical Asia and elsewhere.

In the following section, we outline the SR methodology. The subsequent section draws the evidence together in a qualitative synthesis and then the implications are discussed.

\section{Methods}

\section{Systematic review}

For this SR, we followed the Collaboration for Environmental Evidence (CEE) guidelines (Pullin et al. 2018). As this review was concerned with determining the effects of 
an intervention within a specified population, we followed the concept of defining the Population, Intervention, Comparators and Outcomes (PICO) to inform the search and the criteria for inclusion and exclusion of literature. The criteria for this SR were (i) the Populations: farmers, communities, governments and non-government organisations (NGOs) in tropical Asian climates experiencing drought; (ii) Intervention: any coordinated (e.g. by government or NGO) financial intervention intended to respond to risks associated with drought by either anticipating and mitigating potential impacts or facilitating the recovery from impacts. Thus, interventions could include ex post financial assistance, crop insurance or subsidies; (iii) Comparator: no intervention (that is instances where the searches returned articles concerned with the target population and outcomes but without the explicit discussion or analysis of a specific financial intervention related to managing drought risk) and (iv) Outcomes: evidence of the results or effects linked to interventions (or comparator) at micro- or macrolevels. Whilst the PICO criteria guided the search, we note the objective was to compile a body of literature to evaluate the evidence linking financial assistance and resilience and, as such, interventions and comparators were not defined in the sense of experimental or quasi-experimental design but rather as comparable situations where confounding variables might not necessarily be isolated. We defined tropical Asia using the Köppen-Geiger classification system (Kottek et al. 2006), noting that some countries (particularly India, Myanmar, Lao and Vietnam) may overlap with the hot semi-arid climate region or the humid sub-tropics, and focused the search on Development Assistance Committee (DAC) List countries (OECD, 2021).

\section{Searching and screening}

Keyword searches were undertaken in academic journal databases Scopus and Web of Science in February 2021. The keyword searches, using Boolean operators and wildcards aimed to return a body of literature that met the PICO criteria (see Supplementary Material - Table 1). Journal articles were limited to those published in English and published during the decade March 2011 to February 2021. The selected time period was based on initial exploratory searches that indicated few studies published in earlier years. Secondly, the search period was limited due to potential changes over time in climate, socio-economics, governance, agricultural populations and practices, crop varieties and so on. Other databases including Agris, ProQuest and Google Scholar were reviewed to check for completeness of the dataset, help refine keyword searches and to identify a supplementary selection of literature. For Google Scholar, the first ten pages of results (advanced search terms with 'all the words anywhere in the article': tropical, Asia, drought, financial compensation, intervention, insurance, adaptation; years 2011-2021) were reviewed and relevant journal articles were saved to the library and downloaded $(n=31$, the total number of results returned was in excess of 15,000). Similar searches were performed in Agris $(n=12)$ and ProQuest $(n=22)$, which both returned relatively few results. We used the ROSES flow diagram for SRs to summarise the articles included in searching, screening and synthesis (Fig. 1).

The searches were exported from the databases and organised in Microsoft Excel where duplicate records were removed to give a complete corpus of unique articles $(n=502)$. Articles were excluded at the title and abstract screening if they did not focus on financial interventions for drought in tropical Asia but rather focused on crop variety genetics (drought resilient), other hazards (such as hailstorms or floods), other regions (such as Africa, West or Central Asia), aquaculture or statistical modelling of weather insurance indices. In a number of cases, the financial intervention was inferred as an implication of the research but was not central to the study and such articles were excluded. Following the screening of the title and abstract, the full texts of $n=68$ articles were searched and $n=63$ returned. The full-text articles were then imported into NVivo to assist with coding against the PICO criteria where a further 20 articles were excluded because (i) the details of intervention were not clear, (ii) outcomes were not obviously linked to interventions, (iii) the article was not focused on drought (but rather land degradation and erosions, as examples), (iv) the article was not regionally or climatically specific and (v) two articles were excluded as they were by authors already included in the corpus and relied on the same datasets.

\section{Synthesis}

This study was concerned with the thematic outcomes linked to different financial interventions, noting that we anticipated a range of interactional contexts and variables such as by demographics (e.g. age, gender, level of education), crop, farm-scale or cultural context. Coded text was organised in matrix tables to aid in the sorting and thematic categorisation. We indicated whether the intervention was perceived as either positively $(+)$ or negatively $(-)$ influencing the outcome, for example the intervention might have positively influenced crop yield. We also recorded if the influence was uncertain (or ambiguous, inconclusive or negligible) $(+/-)$. We quantified the number of articles that linked each intervention to an outcome; however, these numbers were for illustrative purposes and not used for statistical inference due to the sample sizes. We used the sorting and tabulation of codes and themes to draw the evidence together and to then interpret the extent to which interventions with varying 

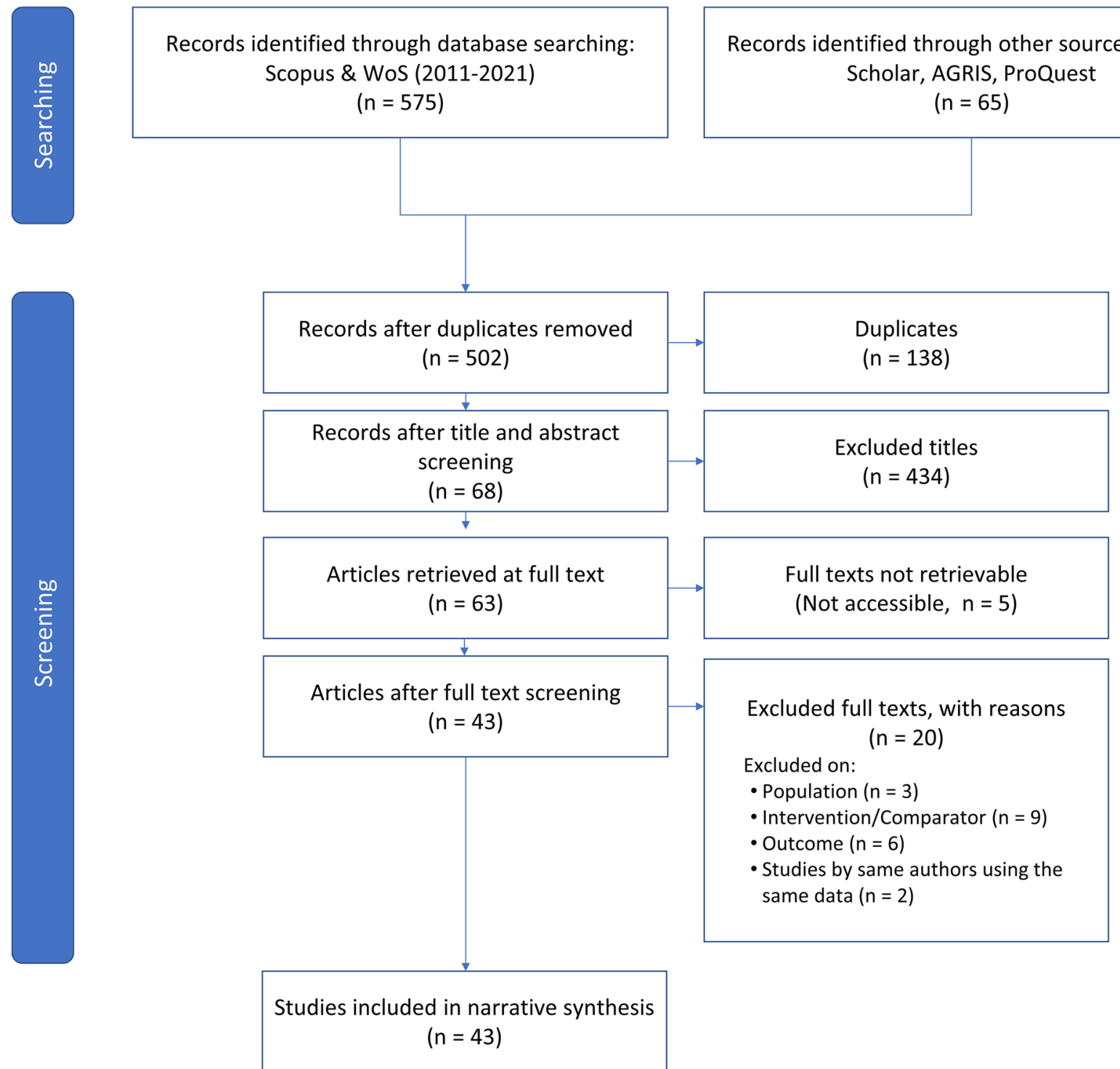

Fig. 1 Flow diagram for searching and screening articles (based on ROSES flow diagram, Haddaway et al. 2017a)

form and function were contributing to drought adaptation and resilience of agricultural systems in tropical Asia.

\section{Results}

Most articles related to individual countries $(n=40)$, whilst three referred to multiple countries in the region. Articles relating to India $(n=24)$ were the most prominent in the corpus (Fig. 2). Most articles reported empirical studies that sampled farmers in their study locations and used survey instruments $(n=31)$, with many involving quantitative choice experiments (including willingness to pay, contingent valuations). The median survey sample size used in these quantitative studies was 380 (range 100 to 3614). Other studies used qualitative methods, including interviews and focus groups with sample sizes ranging from approximately 30 to over 500 (47 focus groups in one study). Some studies analysed secondary data (also including farmer surveys undertaken by national governments) or were reviews of policies or drought support initiatives.

The populations described in the selected articles were farmers, farming households, farming communities, community organisations, governments (national, state, local), NGOs, international aid organisations, banks and money lenders, agribusinesses and private insurance companies. The financial interventions described in the articles were (i) ex post compensation (e.g. government assistance or aid); (ii) ex ante subsidies (also including grant payments); (iii) ex ante centralised investment in irrigation infrastructure or 


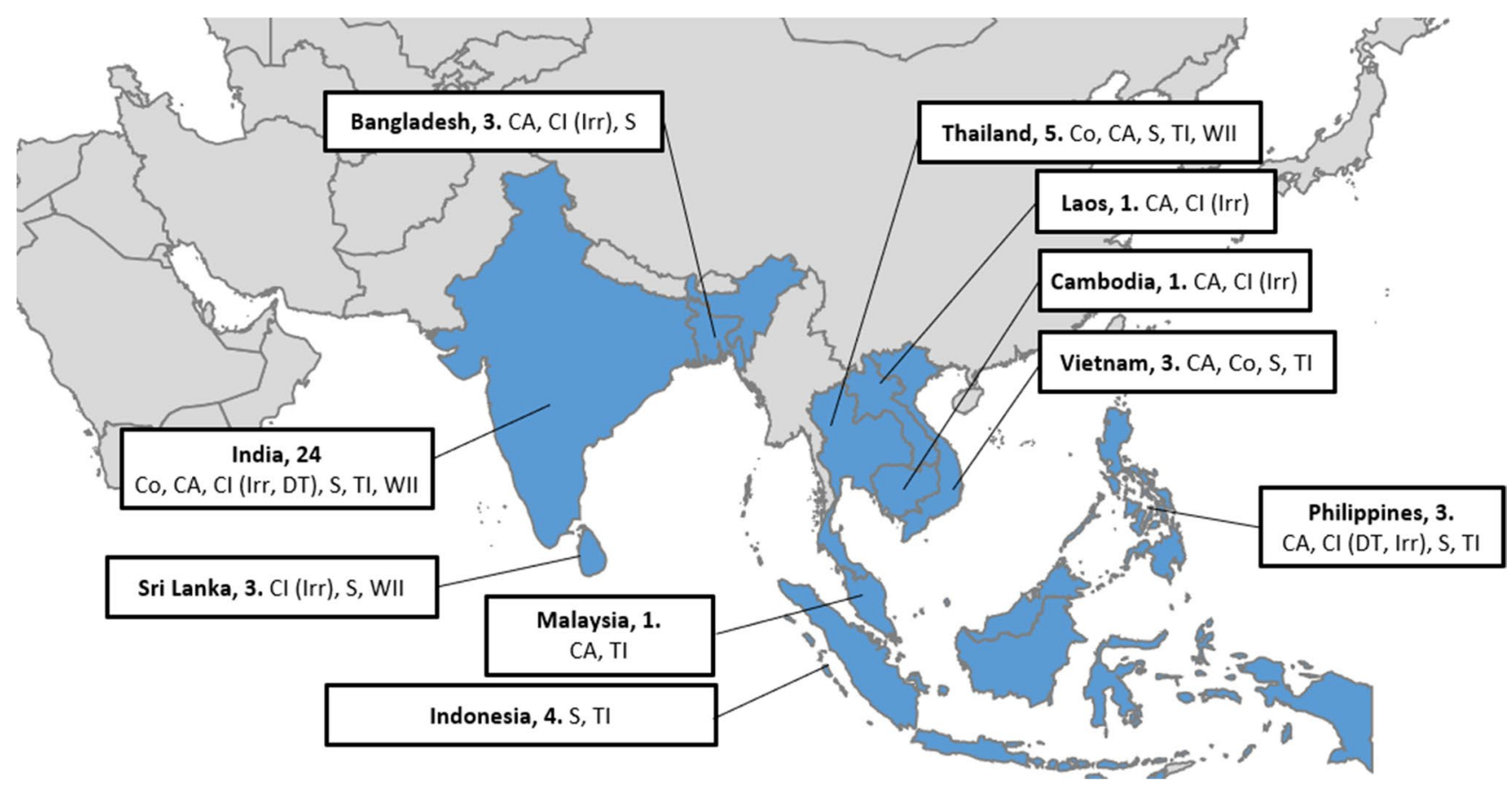

Fig. 2 Countries represented in the SR (some from multi-country studies), including the number of articles in the corpus referring to that country and the types of schemes. Co, compensation; $\mathrm{CA}$, credit

development of drought tolerant seed varieties (also with subsided distribution in some instances); (iv) traditional insurance (indemnity); (v) weather index insurance and (vi) access to credit (including government subsidised loans and micro-finance initiatives). The outcomes are described in the following sections. Micro-level outcomes were linked to interventions in 35 articles, whilst macro-level outcomes were linked in 37 articles (see Table 1).

\section{Micro-level outcomes}

Three categories of micro-level outcomes were identified as associated with interventions (Table 1): (i) outcomes associated with farm finances were the most prominent $(77 \%$ of the 35 articles coded as linking interventions to farm financial outcomes, Table 1), (ii) farm productivity (51\% of coded articles), where the intervention may have supported better yields during drought or helped farmers increase their productivity and (iii) adaptive behaviours (43\% of coded articles), where the intervention was associated with the farm changing something for drought management. With all interventions considered jointly, most outcomes were coded as being positively influenced (66\%); however, many of the references were also coded as uncertain $(51 \%)$ or as being negatively influenced (51\%). Of the interventions, centralised investment was most frequently described as having a positive influence on outcomes (67\% of coded articles), access; CI, central investment (DT, drought-tolerant seeds; Irr, irrigation); S, subsidy; TI, traditional insurance; WII, weather index insurance

whilst insurance (indemnity) had the highest occurrence of references negatively associated with outcomes (69\%). The absence of an intervention was most frequently coded as a negative association with the micro-level outcomes (56\%). Throughout the corpus, it was apparent that outcomes were not experienced homogeneously. Generally, poorer and lesseducated farmers with smaller land sizes and without access to irrigation facilities were described as being disproportionally affected by drought and less likely to access financial dispensation, credit or insurance schemes (as found by Habiba et al. 2014; Bordey and Arida, 2015; Gaurav, 2015; Dewi et al. 2018; Brown et al. 2019; Senapati, 2020). These characteristics were also associated with farmers' propensity to migrate to urban areas or to be trapped in cycles of debt.

\section{Farm finances}

In this subsection, we describe the identified interactions between specific interventions and outcomes relating to farm finances. Compensation and centralised investment were cited as mostly having a positive influence on farm finances. Compensation helped improve income, including improved business and job opportunities after a drought (Habiba et al. 2014; Sharma and Sen, 2021). Central investment in irrigation infrastructure created employment that could help improve farmers' income (Arora and Birwal, 2017), whilst the adoption of certified seeds developed through public rice 
Table 1 Summary of coded outcomes $([+]$, green $]=$ positive, $[+/-]$, amber $=$ uncertain, $[-]$, red =negative). Percentages are for articles coded as linking intervention to a micro- or macro-level outcome (refer to Supplementary Materials Table 2 and Table 3 for more details of coding)

\begin{tabular}{|c|c|c|c|c|c|c|c|c|c|c|c|c|c|}
\hline \multirow[b]{2}{*}{ Intervention } & \multirow[b]{2}{*}{$\begin{array}{c}n^{a} \\
\text { (micro) }\end{array}$} & & \multicolumn{4}{|c|}{ Micro-level Outcomes ${ }^{b}$} & \multirow[b]{2}{*}{$\begin{array}{c}n^{\mathrm{a}} \\
\text { (macro) }\end{array}$} & \multicolumn{6}{|c|}{ Macro-Level Outcome ${ }^{b}$} \\
\hline & & & $\begin{array}{c}\text { Total } \\
\text { micro-level }\end{array}$ & Farm finances & $\begin{array}{c}\text { Farm } \\
\text { productivity }\end{array}$ & $\begin{array}{c}\text { Adaptive } \\
\text { behaviour }\end{array}$ & & $\begin{array}{c}\text { Total macro- } \\
\text { level }\end{array}$ & $\begin{array}{c}\text { Government } \\
\text { finances }\end{array}$ & $\begin{array}{c}\text { Scheme } \\
\text { administration }\end{array}$ & Social & Economic & Environmental \\
\hline \multirow{4}{*}{$\begin{array}{c}\text { All } \\
\text { interventions }\end{array}$} & \multirow{4}{*}{35} & $\begin{array}{c}\% \text { of coded } \\
\text { articles }\end{array}$ & $100 \%$ & $77 \%$ & $51 \%$ & $43 \%$ & \multirow{4}{*}{37} & $100 \%$ & $73 \%$ & $81 \%$ & $27 \%$ & $3 \%$ & $11 \%$ \\
\hline & & {$[+]$} & $66 \%$ & $29 \%$ & $31 \%$ & $26 \%$ & & $41 \%$ & $22 \%$ & $35 \%$ & $3 \%$ & $3 \%$ & $3 \%$ \\
\hline & & {$[+/-]$} & $51 \%$ & $34 \%$ & $23 \%$ & $6 \%$ & & $57 \%$ & $32 \%$ & $22 \%$ & $8 \%$ & $3 \%$ & none identified \\
\hline & & {$[-]$} & $51 \%$ & $34 \%$ & $11 \%$ & $11 \%$ & & $81 \%$ & $41 \%$ & $62 \%$ & $19 \%$ & none identified & $8 \%$ \\
\hline \multirow{3}{*}{ Compensation } & \multirow{3}{*}{6} & {$[+]$} & $50 \%$ & $33 \%$ & none identified & $17 \%$ & \multirow{3}{*}{8} & $38 \%$ & none identified & $25 \%$ & \multirow{2}{*}{ none identified } & $13 \%$ & \multirow{3}{*}{ none identified } \\
\hline & & {$[+/-]$} & $17 \%$ & $17 \%$ & none identified & none identified & & $38 \%$ & $25 \%$ & $13 \%$ & & $13 \%$ & \\
\hline & & {$[-]$} & $33 \%$ & none identified & $17 \%$ & $17 \%$ & & $75 \%$ & $50 \%$ & $38 \%$ & $13 \%$ & none identified & \\
\hline \multirow{3}{*}{ Subsidies } & \multirow{3}{*}{9} & {$[+]$} & $67 \%$ & $11 \%$ & $56 \%$ & none identified & \multirow{3}{*}{13} & $23 \%$ & $8 \%$ & $23 \%$ & $8 \%$ & \multirow{3}{*}{ none identified } & none identified \\
\hline & & {$[+/-]$} & $44 \%$ & $11 \%$ & $33 \%$ & $11 \%$ & & $23 \%$ & $8 \%$ & $15 \%$ & none identified & & $8 \%$ \\
\hline & & {$[-]$} & $33 \%$ & $11 \%$ & none identified & $22 \%$ & & $69 \%$ & $23 \%$ & $38 \%$ & $15 \%$ & & $15 \%$ \\
\hline \multirow{3}{*}{$\begin{array}{l}\text { Centralised } \\
\text { investment }\end{array}$} & \multirow{3}{*}{11} & {$[+]$} & $73 \%$ & $36 \%$ & $36 \%$ & $27 \%$ & \multirow{3}{*}{14} & $14 \%$ & none identified & $14 \%$ & none identified & \multirow{3}{*}{ none identified } & \multirow{3}{*}{ none identified } \\
\hline & & {$[+/-]$} & $9 \%$ & none identified & $9 \%$ & none identified & & $71 \%$ & $57 \%$ & $7 \%$ & $7 \%$ & & \\
\hline & & {$[-]$} & $27 \%$ & none identified & $18 \%$ & $9 \%$ & & $36 \%$ & $29 \%$ & $21 \%$ & $7 \%$ & & \\
\hline \multirow{3}{*}{$\begin{array}{l}\text { Insurance } \\
\text { (indemnity) }\end{array}$} & \multirow{3}{*}{13} & {$[+]$} & $46 \%$ & $15 \%$ & $15 \%$ & $23 \%$ & \multirow{3}{*}{13} & $23 \%$ & $23 \%$ & $8 \%$ & none identified & \multirow{3}{*}{ none identified } & \multirow{3}{*}{ none identified } \\
\hline & & {$[+/-]$} & $31 \%$ & $23 \%$ & $15 \%$ & none identified & & $15 \%$ & $8 \%$ & $8 \%$ & $8 \%$ & & \\
\hline & & {$[-]$} & $69 \%$ & $54 \%$ & none identified & $8 \%$ & & $92 \%$ & $38 \%$ & $92 \%$ & none identified & & \\
\hline \multirow{3}{*}{ Index insurance } & & {$[+]$} & $14 \%$ & & $14 \%$ & none identified & & $56 \%$ & $44 \%$ & $56 \%$ & & & \\
\hline & 7 & {$[+/-]$} & $71 \%$ & $71 \%$ & $14 \%$ & $14 \%$ & 9 & $22 \%$ & & $22 \%$ & none identified & none identified & none identified \\
\hline & & & $43 \%$ & $29 \%$ & none identified & $14 \%$ & & $78 \%$ & $22 \%$ & $44 \%$ & & & \\
\hline & & {$[+]$} & $46 \%$ & $15 \%$ & & $38 \%$ & & $20 \%$ & $20 \%$ & & none identified & & \\
\hline Credit access & 13 & {$[+/-]$} & $23 \%$ & $15 \%$ & $8 \%$ & & 5 & $40 \%$ & nope identified & none identified & $40 \%$ & none identified & none identified \\
\hline & & {$[-]$} & $38 \%$ & $31 \%$ & $8 \%$ & $8 \%$ & & $80 \%$ & none identified & $80 \%$ & $60 \%$ & & \\
\hline & & $\begin{array}{c}\% \text { of coded } \\
\text { articles }\end{array}$ & $100 \%$ & $44 \%$ & $48 \%$ & $56 \%$ & & $100 \%$ & n/a & $n / a$ & $93 \%$ & $36 \%$ & $14 \%$ \\
\hline No intervention & & {$[+]$} & $36 \%$ & $4 \%$ & $12 \%$ & $28 \%$ & 14 & $0 \%$ & n/a & $n / a$ & none identified & eidentified & pone identified \\
\hline & 25 & {$[+/-]$} & $44 \%$ & $32 \%$ & none identified & $16 \%$ & & $7 \%$ & $n / a$ & $n / a$ & $7 \%$ & none identified & none identified \\
\hline & & {$[-]$} & $56 \%$ & $24 \%$ & $40 \%$ & $16 \%$ & & $93 \%$ & n/a & $n / a$ & $86 \%$ & $36 \%$ & $14 \%$ \\
\hline
\end{tabular}

${ }^{\mathrm{a}}$ Number of articles coded as linked to outcomes for each intervention. ${ }^{\mathrm{b}}$ Bars show the proportion of the articles linking intervention to outcomes coded as either positive, uncertain or negative influence on the outcome, may not sum to $100 \%$ as an article could include details of both positive, uncertain or negative influences on outcomes

breeding research in the Philippines also provided opportunities for farmers to improve their income due to better yields during droughts (Mariano et al. 2012).

Government subsidies for electricity were recommended by farmers in India to help initiate additional income-generating activities and thus build financial resilience to drought (Habiba et al. 2014). In the case of conditional payments for ecosystem services in Thailand, farmers were likely to opt for riskier, higher-income activities that may be less resilient to climate shocks (Kanchanaroek and Aslam, 2018).

Insurance (indemnity) was often negatively associated with income (in 54\% of the articles referring to such insurance schemes): firstly, because the premium was considered a financial burden (Bordey and Arida, 2015) and, secondly, because crops could be damaged by drought but the farmer did not receive any insurance payment (Singh and Agrawal, 2020). The classification of references to index insurance was mostly uncertain (71\%), as it could help smooth income (Prasada, 2020) but compensation levels could be variable and not always adequate (Ghosh et al. 2021). Credit access, including through micro-finance initiatives, also helped farmers invest in income-generating activity (Habiba et al. 2014); however, it was more often negatively associated with high repayments (Brown et al. 2019) and debt (Taylor, 2011).
The absence of intervention was linked to micro-level outcomes in 25 of the articles, with $44 \%$ of these relating to farm finances. Whilst farmers experienced economic losses (Bahinipati, 2020) and reduced income (Ho et al. 2021) due to drought, some were able to autonomously protect their income through diversification of income sources (Arora and Birwal, 2017), and even increase it through shifting to higher profit crops (Habiba et al. 2014).

\section{Farm productivity}

Without intervention, farms typically experienced crop losses (Pasaribu and Sudiyanto, 2016) and production declines during drought (Kishore et al. 2015). Subsidies and government investment were the two categories of interventions with the highest proportion of positive associations with farm productivity.

Improved productivity was linked to government subsidies in a number of articles relating to cocoa farming in Indonesia (Tothmihaly and Ingram, 2019), rice and wheat in India (Kishore et al. 2019) and rice in Sri Lanka (Williams and Carrico, 2017). In these cases, the subsidy included support for fertilisers, seed varieties, pumps and electricity. On the other hand, subsidised diesel for irrigation pumps was described as ineffective for a scheme in India (Kishore et al. 2019). Another study (Kanchanaroek 
and Aslam, 2018) found that payments for ecosystem services attracted farmers to change their land use and land management practices; however, this did not relate to an increase in productivity.

Government infrastructure investment was associated with yield improvements. One article described benefits to a centrally funded and managed irrigation scheme in Sri Lanka (Burchfield et al. 2018) and another recommended access to affordable irrigation as the best stimulus for agricultural production (Kishore et al. 2019). However, another study suggested that reliance on irrigation infrastructure rather than crop diversification had a negative association with yield during drought due to the limited water availability (Auffhammer and Carleton, 2018). Other central investment schemes included the development of hybrid seeds (that were also distributed to farmers with institutional involvement) that correlated with better rice yields (Williams and Carrico, 2017).

\section{Adaptive behaviour}

Proportionally, credit access had the most articles positively associated with adaptive behaviour. Credit access helped facilitate investments in adaptation, including diversifying livelihoods (Reddy and Sahu, 2013), and was cited as helping to improve resilience (Ho et al. 2021). Crop insurance was also shown to correlate with an increased likelihood of engaging in yield raising adaptations, although insurance could influence riskier production decisions, such as crop choice and usage of agricultural inputs (Sinha and Tripathi, 2016), that were less resilient to climate shocks (Panda et al. 2013).

Centralised investment in irrigation was positively associated with improved farm management and adaptation (Mariano et al. 2012); however, such interventions were also negatively associated with adaptive behaviour as they could discourage crop diversification (Auffhammer and Carleton, 2018). Similarly, government subsidies were coded as negatively influencing adaptive behaviours, for example input subsidies encouraged undesirable land management practices (Ghosh et al. 2021).

With no intervention, farmers exhibited a range of adaptive behaviours with both positive and negative implications. For example, farmers were adapting their land and water management, diversifying their livelihoods and protecting themselves through self-insurance (e.g. Ghosh et al. 2021). However, it was also evident that there was low engagement with diversification (Bordey and Arida, 2015; Prasada, 2020) and limitations to the resilience of self-insurance to extreme or successive shocks (Gaurav, 2015), particularly for more vulnerable groups.

\section{Macro-level outcomes}

The following macro-level outcomes were categorised as being associated with the interventions (Table 1): (i) government finances (73\% of the 37 articles coded as linking interventions to macro-level financial outcomes), (ii) scheme administration ( $81 \%$ of the coded articles) and (iii) social (27\%), economic (3\%) or environmental (11\%) impacts.

With all interventions considered together, the majority of outcomes was coded as being negatively influenced (81\%); however, many references were also coded as uncertain $(57 \%)$ and positive $(41 \%)$. Of the interventions, index insurance was most frequently described as having a positive influence on outcomes (56\% of the coded articles). All interventions had more negatively coded references, with the exception of centralised investment, where the majority of codes was uncertain. With no intervention, the macro-level outcomes were almost entirely coded as negative (93\%) and mostly related to social impacts ( $86 \%$ of coded articles).

\section{Government finances}

In this subsection, we describe in more detail the identified interactions between specific interventions and outcomes relating to government finances. Most interventions were observed to have a negative influence on government finances, mainly through the burden of costs. As such, funds were diverted away from other spending priorities (Prasada, 2020; Sharma and Sen, 2021) and were often insufficient to sustain a scheme, whether it be post-disaster compensation (Sharma, 2019) or the ongoing maintenance and repair of infrastructure investments (Beckman and Nguyen, 2016; Brown et al. 2019). In India, the central government's transfer of drought management financial obligations to the States led to the States being financially more stressed, in part due to arranging and deploying resources (Sharma, 2019).

Traditional insurance schemes were reported as an inefficient use of tax revenue (Ghosh et al. 2021) that were often not financially sustainable (Singh and Agrawal, 2020) due to high running costs (Alam et al. 2020). Whilst index insurance had more positively coded references, this was framed by a relative comparison to traditional insurance products where index-based products were more attractive to governments and private insurers as they were less expensive to run (Bordey and Arida, 2015; Prasada, 2020). Some governments saw subsidising insurance as more cost-effective than post-disaster compensation; however, some farmers preferred compensation (Sinha and Tripathi, 2016).

\section{Scheme administration}

Across all micro- and macro-level outcomes, factors influencing scheme administration had the most references coded 
in the most articles (30 articles or $81 \%$ of articles coded with macro-level outcomes). The administration of some schemes was positively influenced by having standardised rules to declare droughts and issue compensation (Sharma, 2019), by stakeholder collaboration relating to subsidy schemes (Bastakoti et al. 2014) and by being seen as easier to run than other schemes, particularly relating to index insurance (Ward and Makhija, 2018).

However, except for index insurance, all interventions had more negatively coded references relating to scheme administration. One negative factor was the low participation of farmers or limited coverage which led to administrative inefficiencies for schemes including compensation (Pasaribu and Sudiyanto, 2016), subsidies (Kanchanaroek and Aslam, 2018) and insurance (Dewi et al. 2018). There were many negative outcomes associated with insurance schemes and subsidy schemes where the administrative burden was greater due to the need to assess many applications and process numerous transactions. Central investment in water supply infrastructure also placed an administrative burden on governments through the continual need to coordinate maintenance_also linked to government finance (Palis et al. 2015; Kishore et al. 2019).

\section{Wider social, economic and environmental impacts}

Wider impacts were observed to be associated with the financial interventions, although a higher number of adverse outcomes were coded as being associated with no intervention. Of all the interventions, only one article was coded as having a positive outcome. This was a positive economic impact from compensation on the industrial sector and the district economy (Sharma and Sen, 2021). Many of the negative outcomes from interventions were social and related to farmers' reliance on credit (including micro-credit) which led to cycles of indebtedness (Gaurav, 2015) and poverty (Palis et al. 2015).

Without some intervention, the most prominent impacts (in terms of the number of articles coded) were social (poorer farmers changed job, migrated to urban areas or suffered poor physical or mental health-Arora \& Birwal, 2017; Chandra Sekhar Bahinipati, 2020; Gaurav, 2015), followed by economic (decreased productivity in the agricultural sector, regional and national economies) and environmental (pollution, land degradation) (Habiba et al. 2014; Bahinipati, 2020; Suryanto et al. 2020; Ho et al. 2021).

\section{Discussion}

This review set out to contribute to the understanding of the form and function (including timing) of financial interventions and to how the link between institutional responses to drought and agricultural adaptations and resilience might be strengthened in tropical Asia. We found evidence of outcomes being influenced by the financial interventions at both the micro (or farm) level and at a macro-level.

\section{Micro-level outcomes}

The micro-level outcomes related to farm finances, farm productivity and farmers' adaptive behaviour, which, on balance, were collectively described as being more positively influenced by the interventions. The interventions were also associated with more positive outcomes for farm finances and farm productivity when compared to having no intervention. However, farmers were similarly likely to demonstrate positive adaptive behaviour with or without a formal intervention (noting the limitations to these cross-study comparisons and also noting variations in the frequency of adaptive behaviours cited as an outcome depending on the intervention). With no intervention, some farmers undertook autonomous risk management like crop diversification or selling livestock to sustain incomes during drought, although many farmers lacked the resources to make their desired changes. Access to formal institutional credit helped support adaptive behaviour but was not typically available to all demographics, hence, drawing attention to the need for interventions to reach the most vulnerable groups (Cutter et al. 2012). Lack of credit access can be a major constraint on farmers' ability to adapt to drought conditions and micro-finance initiatives may be an appropriate tool in some circumstances (Khanal and Regmi, 2018). Informal risk sharing may continue to help many farmers cope in the short term, particularly for those who are less wealthy and do not have access to institutional financial support (Bastakoti et al. 2014; Gaurav, 2015; Palis et al. 2015); however, this route is less likely to strengthen adaptive capacity nor enhance the resilience of the farming system.

\section{Macro-level outcomes}

Adaptation can occur at both the farm scale and at national or regional scales, for example, through drought management policy iterations (Habiba et al. 2014). Moreover, drought management financial obligations can vary between national and state levels of government (Sharma, 2019), or between nations included in this review, that may also differ in their capacity to manage and influence resilience. Macrolevel consequences associated with the interventions related to government finances, scheme administration and wider social, economic and environmental impacts. The review did not uncover evidence of positive macro-level adaptation trends that might support resilience. Rather, institutions were described as struggling to maintain the required budgets and administrative arrangements to deliver desired scheme 
impacts. The results suggested that institutions need to weigh up interactions and trade-offs between social, environmental and economic outcomes related to financial interventions. Many schemes had not accounted for non-economic losses that might include health impacts, damage to wildlife or loss of biodiversity (Bahinipati, 2020). As an example, a government scheme to expand access to groundwater irrigation may make farms more productive in the short term (and sustain incomes) but may not foster longer-term resilience as overutilisation of the water source or intensification of production ultimately causes negative environmental impacts (Prasad and Sohoni, 2020). Similar paradoxes can include disinvestment in education in favour of immediate employment in low-skill jobs or encouraging adaptation towards income diversification where specialisation in livestock activities may be a more drought resilient strategy in some circumstances (Gerber and Mirzabaev, 2017). Despite the trade-offs, there were some positive macro-level outcomes associated with the financial interventions that, if sustained, could increase place-based (or community level) adaptive capacity and strengthen farming system resilience through providing regional economic stimulus (Sharma and Sen, 2021) or through decreasing permanent urban migration amongst poor households or decreasing food shortage days (Reddy and Sahu, 2013).

\section{Forms of intervention}

Regarding the form of intervention, we found that coordinated financial interventions can help to avoid the negative impacts of drought and, with the appropriate continual policy support, may help strengthen agricultural resilience in tropical Asia. For some schemes, the precise form was ambiguous as the development of drought-tolerant seeds involved government investment but could also involve subsidies to encourage the broader uptake by farmers. Similarly, governments could centrally invest in developing irrigation infrastructure or provide grants and subsidies to local communities or individuals to build their own water storage and irrigation. The results of this review, albeit based on diverse literature using different methods in different settings, suggest that there may not be one optimal financial intervention (Aakre et al. 2010) but rather country and context-specific solutions (Clarke et al. 2017) that might combine different management interventions (Ward and Makhija, 2018) tailored to the characteristics of the drought risk (LinneroothBayer and Hochrainer-Stigler, 2015) and countries' unique institutional and socio-economic circumstances (Anbumozhi et al. 2012). In the case of subsidising crop insurance, Smith (2016) suggests that more evidence is needed on the relative returns compared to other uses of the money such as subsiding conservation practices, providing education and increasing location-specific agricultural research and extension. In terms of fairness and effectiveness, index insurance has been evaluated as better than more traditional indemnity based products (Hazell and Hess, 2010); however, such schemes may not support smallholder farmers more than informal community-based initiatives, payments will not necessarily correlate well with actual losses, and subsided access may be sub-optimal for encouraging longer-term investments in risk management (Smith, 2016).

\section{Timing of intervention}

In terms of intervention timing, we found advantages and disadvantages to both ex post and ex ante schemes, noting that it was sometimes unclear where intervention was in a given sequence of droughts (e.g. the intervention followed one drought and preceded the next). There may be some benefits to governments providing ex post crisis management support funds (Zhou and Shao-Yu, 2013) but such stimulus is unlikely to facilitate longer-term resilience (Habiba et al. 2014; Sharma and Sen, 2021) if farmers become dependent on compensation nor where prioritising short-term needs does not facilitate the building of capacity to adapt away from existing vulnerabilities (Cutter et al. 2012; Wilhite et al. 2013; Carrão et al. 2016). Ex ante support is mooted as the more desirable time to intervene (Linnerooth-Bayer and Hochrainer-Stigler, 2015; Gerber and Mirzabaev, 2017; Guimarães Nobre et al. 2019), but such approaches can still be challenged in practice by scheme administration issues, budget constraints and demographic or farm-level heterogeneity. A more need-based adaptation planning approach could help integrate various farm-level needs with centrally coordinated interventions (Singh et al. 2018), which may help mainstream adaptive practices as well as strengthen institutional capabilities (Aryal et al. 2020). In summary, there may be several more easily implementable, low-cost drought management investments that can be made such as extension support, supporting indigenous knowledge networks, improving the communication of formal advice, upscaling local climate resilient practices, that also have added social or economic co-benefits (Rao et al. 2016; Gerber and Mirzabaev, 2017) and that would help mainstream adaptation in the long run (Prabhakar and Shaw, 2008) as an enduring characteristics of a resilient farming system (Meuwissen et al. 2019).

\section{Conclusions}

Agriculture in tropical Asia is sensitive to drought and associated impacts. By exploring the influence of several types of financial interventions described in the academic literature on micro- and macro-level outcomes, we were able to infer the potential to support adaptation towards more 
drought-resilient agriculture. At a farm level, interventions help to sustain crop yields and protect farmers' income during drought. The interventions were also associated with adaptive behaviours where farmers were able to make changes and increase their capacity to make their livelihoods more resilient. At a macro-level, governments were challenged by the budgetary and administrative demands of running many of the schemes. Interventions were also linked to wider social, economic and environmental impacts which implied a need for more integrative scheme monitoring and evaluation. Whilst there may be no optimal solutions, mixes of instruments may bring benefits when tailored to specific contexts and levels of risk. The evidence, albeit of varying quality and strength and set in cross-national contexts, suggests that there are challenging policy trade-offs for institutions to make between supporting livelihoods and economic growth whilst also protecting the environment and sustaining local communities. The design of schemes should benefit from deeper consultation with farmers, undertaking need-based assessment and supporting the promotion (and upscaling) of effective community-level adaptive practices. Evidenced by the low participation rate of many schemes integrated packages of support may help reach a greater diversity of farmers and should aim to account for different literacy and wealth levels of farmers across the region, thus reinforcing the higher vulnerabilities of certain groups or sectors within the farming system. A focus on low-regret investments may help reduce vulnerabilities and mainstream adaptation as an ongoing, reflexive evaluation of system resilience. In this regard, agricultural extension, local experimentation, social networks and social learning may play important roles in strengthening the elements of agricultural systems contributing to reorganisation but also to maintaining the more desirable configurations. To conclude, further research should aim to evaluate such financial interventions using more controlled experimental (or quasi-experimental) methods so that the quality and strength of evidence on the relative advantages and disadvantages of different strategies can be more rigorously weighed up and synthesised. The relative sparsity of studies in countries within the region highlights an opportunity for inter-regional and cross-national collaboration.

Supplementary Information The online version contains supplementary material available at https://doi.org/10.1007/s10113-021-01867-y.

Funding This project was funded through a Global Challenges Research Fund QR 2020/21 grant and a joint grant from NERC (Natural Environment Research Council, UK), grant number NE/S003223/1 and TSRI (Thailand Science Research and Innovation), grant number RDG6130017 for the STAR project (Strengthening Thailand's Agricultural drought Resilience)

No new data were created in this study. The authors confirm that the articles used in the literature review are cited in the article. The coding of articles is summarised in the supplementary materials. Any enquiries can be directed to the authors.

\section{Declarations}

Ethics approval Ethics was approved the Cranfield University Research Ethics System (CURES), reference: CURES/12888/2021.

Open Access This article is licensed under a Creative Commons Attribution 4.0 International License, which permits use, sharing, adaptation, distribution and reproduction in any medium or format, as long as you give appropriate credit to the original author(s) and the source, provide a link to the Creative Commons licence, and indicate if changes were made. The images or other third party material in this article are included in the article's Creative Commons licence, unless indicated otherwise in a credit line to the material. If material is not included in the article's Creative Commons licence and your intended use is not permitted by statutory regulation or exceeds the permitted use, you will need to obtain permission directly from the copyright holder. To view a copy of this licence, visit http://creativecommons.org/licenses/by/4.0/.

\section{References}

Aakre S, Banaszak I, Mechler R, Rübbelke D, Wreford A et al (2010) Financial adaptation to disaster risk in the European Union: identifying roles for the public sector. Mitig Adapt Strat Glob Change 15(7):721-736. https://doi.org/10.1007/s11027-010-9232-3

Abid M, Scheffran J, Schneider UA, Ashfaq M (2015) Farmers' perceptions of and adaptation strategies to climate change and their determinants: the case of Punjab province, Pakistan. Earth System Dynamics 6(1):225-243. https://doi.org/10.5194/esd-6-225-2015

Alam ASAF, Begum H, Masud MM, Al-Amin AQ, Leal Filho W (2020) 'Agriculture insurance for disaster risk reduction: a case study of Malaysia', International Journal of Disaster Risk Reduction. Elsevier 47:101626. https://doi.org/10.1016/j.ijdrr.2020. 101626

Anbumozhi V, Breiling M, Pathmarajah S, Reddy VR (2012) Climate change in Asia and the Pacific how can countries adapt? SAGE Publications Ltd

Arora A, Birwal D (2017) Natural calamities, crop losses and coping strategies: an economic analysis from Odisha. Indian J Agric Econ 72(3):385-395

Aryal JP, Sapkota TB, Khurana R, Khatri-Chhetri A, Rahut DB et al (2020) Climate change and agriculture in South Asia: adaptation options in smallholder production systems, Environment, Development and Sustainability. Springer Netherlands. https://doi.org/ 10.1007/s10668-019-00414-4

Auffhammer M, Carleton TA (2018) Regional crop diversity and weather shocks in India. Asian Dev Rev 35(2):113-130. https:// doi.org/10.1162/adev_a_00116

Bahinipati CS (2020) Assessing the costs of droughts in rural India: a comparison of economic and non-economic loss and damage. Curr Sci 118(11):1832-1841. https://doi.org/10.18520/cs/v118/ i11/1832-1841

Bastakoti RC, Gupta J, Babel MS, van Dijk MP (2014) Climate risks and adaptation strategies in the Lower Mekong River basin. Reg Environ Change. https://doi.org/10.1007/s10113-013-0485-8

Beckman M, Nguyen MVT (2016) Upland development, climaterelated risk and institutional conditions for adaptation in Vietnam. Clim Dev Taylor \& Francis 8(5):413-422. https://doi.org/10.1080/ 17565529.2015.1067178 
Bordey FH, Arida IA (2015) Adoption of rice crop insurance in the Philippines: lessons from farmer's experience. Philipp J Crop Sci 40(1):24-34

Bradshaw B, Dolan H, Smit B (2004) Farm-level adaptation to climatic variability and change: crop diversification in the Canadian prairies. Clim Change 67(1):119-141. https://doi.org/10.1007/ s10584-004-0710-z

Brown PR, Afroz S, Chialue L, Chiranjeevi T, El S et al (2019) Constraints to the capacity of smallholder farming households to adapt to climate change in South and Southeast Asia. Clim Dev Taylor \& Francis 11(5):383-400. https://doi.org/10.1080/17565529. 2018.1442798

Burchfield E, Williams NE, Carrico AR (2018) Rescaling drought mitigation in rural Sri Lanka Regional Environmental Change. Reg Environ Change 18(8):2495-2503. https://doi.org/10.1007/ s10113-018-1374-y

Carrão H, Naumann G, Barbosa P (2016) Mapping global patterns of drought risk: an empirical framework based on sub-national estimates of hazard, exposure and vulnerability. Glob Environ Chang 39:108-124. https://doi.org/10.1016/j.gloenvcha.2016.04.012

Carter R, Ferdinand T, Chan C (2018) Transforming agriculture for climate resilience: a framework for systemic change. WRI Publications, World Resources Institute

Clarke DJ, Mahul O, Poulter R, Teh TL (2017) 'Evaluating sovereign disaster risk finance strategies: a framework', Geneva Papers on Risk and Insurance: Issues and Practice. Palgrave Macmillan UK 42(4):565-584. https://doi.org/10.1057/s41288-017-0064-1

Cutter SL, Barnes L, Berry M, Burton C, Evans E et al (2008) A placebased model for understanding community resilience to natural disasters. Glob Environ Chang 18(4):598-606. https://doi.org/10. 1016/j.gloenvcha.2008.07.013

Cutter S, Osman-Elasha B, Campbell J, Cheong S-M, McCormick S et al (2012) Managing the risks from climate extremes at the local level. In: Field CB, Barros V, Stocker TF, Qin D, Dokken DJ et al (eds) Managing the risks of extreme events and disasters to advance climate change adaptation. Cambridge University Press, Cambridge, UK, pp 291-338

Dewi N, Kusnandar, Rahayu ES (2018) 'Risk mitigation of climate change impacts on rice farming through crop insurance: an analysis of farmer's willingness to participate (a case study in Karawang Regency, Indonesia)', IOP Conference Series: Earth and Environmental Science, 200: 012059. https://doi.org/10.1088/ $1755-1315 / 200 / 1 / 012059$.

Engle NL (2011) Adaptive capacity and its assessment. Global Environmental Change Elsevier Ltd 21(2):647-656. https://doi.org/10. 1016/j.gloenvcha.2011.01.019

Field CB, Barros V, Stocker TF, Dahe Q (2012) Managing the risks of extreme events and disasters to advance climate change adaptation: special report of the intergovernmental panel on climate change. Cambridge University Press

Franzetti F, Pezzoli A, Bagliani M (2017) 'Rethinking water resources management under a climate change perspective: from national to local level. The case of Thailand', in Tiepolo, M., Pezzoli, A. and Tarchiani, V. (ed.) Renewing local planning to face climate change in the tropics. Springer Nature

Gaurav S (2015) 'Are rainfed agricultural households insured? Evidence from five villages in Vidarbha, India', World Development. Elsevier Ltd 66:719-736. https://doi.org/10.1016/j.worlddev.2014. 09.018

Gerber N, Mirzabaev A (2017) Benefits of action and costs of inaction: drought mitigation and preparedness-a literature review (N. Gerber and A. Mirzabaev), Integrated Drought Management Programme (IDMP) Working Paper No. 1. Stockholm, Sweden. https://doi.org/10.1201/b22009
Ghosh RK, Gupta S, Singh V, Ward PS (2021) Demand for crop insurance in developing countries: new evidence from India. J Agric Econ 72(1):293-320. https://doi.org/10.1111/1477-9552.12403

Guimarães Nobre G, Davenport F, Bischiniotis K, Veldkamp T, Jongman B et al (2019) 'Financing agricultural drought risk through ex-ante cash transfers', Science of the Total Environment. The Authors, 653(February 2018) 523-535. https://doi.org/10.1016/j. scitotenv.2018.10.406

Habiba U, Shaw R, Takeuchi Y (2014) Farmers' adaptive practices for drought risk reduction in the northwest region of Bangladesh. Nat Hazards 72(2):337-359. https://doi.org/10.1007/ s11069-013-1011-5

Haddaway N, Macura B, Whaley P, Pullin A (2017) 'ROSES flow diagram for systematic reviews. Version 1.0.' https://doi.org/10. 6084/m9.figshare.5897389

Hazell PBR, Hess U (2010) Drought insurance for agricultural development and food security in dryland areas. Food Security. https://doi.org/10.1007/s12571-010-0087-y

Ho TDN, Kuwornu JKM, Tsusaka TW (2021) Factors influencing smallholder rice farmers' vulnerability to climate change and variability in the Mekong Delta Region of Vietnam, European Journal of Development Research. Palgrave Macmillan UK. https://doi.org/10.1057/s41287-021-00371-7

Hurlbert MA, Gupta J (2019) An institutional analysis method for identifying policy instruments facilitating the adaptive governance of drought. Environ Sci Policy. https://doi.org/10.1016/j. envsci.2018.09.017

IRGP and MSC (2019) First insights: landscape of climate and disaster risk insurance (CDRI) in Asia and the Pacific. MicroSave Consulting

Kanchanaroek Y, Aslam U (2018) 'Policy schemes for the transition to sustainable agriculture-farmer preferences and spatial heterogeneity in northern Thailand.' Land Use Policy Elsevier(September 2017) 78:227-235. https://doi.org/10. 1016/j.landusepol.2018.05.026

Kandlikar M, Risbey J (2000) Agricultural impacts of climate change: if adaptation is the answer, what is the question? Clim Change 45(3-4):529. https://doi.org/10.1016/j.urology.2014. 04.064

Khanal AR, Regmi M (2018) Financial constraints and production efficiency: a case from rice growers in drought prone areas of Indonesia. Agric Financ Rev 78(1):25-40. https://doi.org/10. 1108/AFR-07-2016-0068

Kishore A, Joshi PK, Pandey D (2015) Drought, distress, and a conditional cash transfer programme to mitigate the impact of drought in Bihar, India. Water Int Routledge 40(3):417-431. https://doi.org/10.1080/02508060.2015.1050579

Kishore A, Joshi PK, Pandey D (2019) 'Droughts, distress, and policies for drought-proofing agriculture in Bihar, India', Climate Smart Agriculture in South Asia: Technologies, Policies and Institutions, (December) 143-164. https://doi.org/10.1007/ 978-981-10-8171-2_7

Kottek M, Grieser J, Beck C, Rudolf B, Rubel F (2006) World map of the Köppen-Geiger climate classification updated. Meteorol Z 15(3):259-263. https://doi.org/10.1127/0941-2948/2006/0130

Lin BB (2011) Resilience in agriculture through crop diversification: adaptive management for environmental change. Bioscience 61(3):183-193. https://doi.org/10.1525/bio.2011.61.3.4

Linnerooth-Bayer J, Hochrainer-Stigler S (2015) Financial instruments for disaster risk management and climate change adaptation. Clim Change 133(1):85-100. https://doi.org/10.1007/ s10584-013-1035-6

Mariano MJ, Villano R, Fleming E (2012) 'Factors influencing farmers' adoption of modern rice technologies and good management practices in the Philippines', Agricultural Systems. Elsevier Ltd 110:41-53. https://doi.org/10.1016/j.agsy.2012.03.010 
Meuwissen MPM, Feindt PH, Spiegel A, Termeer CJAM, Mathijs E et al (2019) A framework to assess the resilience of farming systems. Agric Syst Elsevier 176(May):102656. https://doi.org/ 10.1016/j.agsy.2019.102656

Mia MS, Er AC, Prabhakar S, Pereira JJ (2015) 'Disaster risks and insurance in the agriculture sector in Asia: a review'. J Food Agric Environ

OECD (2021) DAC List of ODA Recipients. Available at: https://www. oecd.org/dac/financing-sustainable-development/developmentfinance-standards/daclist.htm (Accessed: 27 Sept 2021).

Palis F, Diaz C, Todcor G, Flor RJ, Tanzo I et al (2015) 'Voices from the field: needs of small-scale Filipino rice farmers', Philippine Journal of Crop Science (PJCS). Crop Sci Soc Philipp 40(1):1-7

Panda A, Sharma U, Ninan KN, Patt A (2013) Adaptive capacity contributing to improved agricultural productivity at the household level: empirical findings highlighting the importance of crop insurance. Glob Environ Chang. https://doi.org/10.1016/j.gloen vcha.2013.03.002

Pasaribu SM, Sudiyanto A (2016) 'Agricultural risk management: lesson learned from the application of rice crop insurance in Indonesia', in Climate Change Policies and Challenges in Indonesia. Springer 305-322. https://doi.org/10.1007/978-4-431-55994-8_ 14.

Pavelic P, Srisuk K, Saraphirom P, Nadee S, Pholkern K et al (2012) 'Balancing-out floods and droughts: opportunities to utilize floodwater harvesting and groundwater storage for agricultural development in Thailand', Journal of Hydrology. Elsevier B.V., 470-471, pp. 55-64. https://doi.org/10.1016/j.jhydrol.2012.08.007.

Prabhakar SVRK, Shaw R (2008) Climate change adaptation implications for drought risk mitigation: a perspective for India. Clim Change 88(2):113-130. https://doi.org/10.1007/ s10584-007-9330-8

Prasad P, Sohoni M (2020) Agricultural intensification and risk in water-constrained hard-rock regions: a social-ecological systems study of horticulture cultivation in Western India. Ecol Soc. https://doi.org/10.5751/ES-11825-250402

Prasada DVP (2020) 'Climate-indexed insurance as a climate service to drought-prone farmers: evidence from a discrete choice experiment in Sri Lanka', in Filho, W. L. and Jacob, D. (eds) Handbook of Climate Services

Pullin AS, Frampton GK, Petrokofsky, Gillian BL (2018) Guidelines and standards for evidence synthesis in environmental management version 5, collaboration for environmental evidence. Available at: https://environmentalevidence.org/information-for-autho rs/table-of-contents-page/ (Accessed: 10 Mar 2021).

Rao CS, Gopinath KA, Prasad JVNS, Singh AK (2016) 'Climate resilient villages for sustainable food security in tropical India: concept, process, technologies, institutions, and impacts', Advances in Agronomy 1-114. https://doi.org/10.1016/bs.agron.2016.06.003.

Reddy GB, Sahu N (2013) 'Disaster risk management through a " "Watershed Plus"” approach in the Western Orissa Rural Livelihoods Project (WORLP): Orissa, India', in Filho, W. L. (ed.) Climate Change and Disaster Risk Management. Springer

Reidsma P, Ewert F, Lansink AO, Leemans R (2010) Adaptation to climate change and climate variability in European agriculture: the importance of farm level responses. Eur J Agron 32(1):91-102. https://doi.org/10.1016/j.eja.2009.06.003

Ricome A, Affholder F, Gérard F, Muller B, Poeydebat C et al (2017) 'Are subsidies to weather-index insurance the best use of public funds? A Bio-Economic Farm Model Applied to the Senegalese Groundnut Basin', Agricultural Systems. https://doi.org/10.1016/j. agsy.2017.05.015

SAARC (2010) SAARC Workshop on Drought Risk Management in South Asia. South Asian Association for Regional Cooperation (SAARC) Disaster Management Centre. Available at: www.
droughtmanagement.info/literature/SAARC_drought_risk_manag ement_south_asia_2010.pdf.

Senapati AK (2020) 'Do farmers value insurance against extreme droughts and floods? Evidence from Odisha, India', Global Business Review. https://doi.org/10.1177/0972150920957616

Shaffril HAM, Krauss SE, Samsuddin SF (2018) 'A systematic review on Asian's farmers' adaptation practices towards climate change', Science of the Total Environment. Elsevier B.V., 644, pp. 683695. https://doi.org/10.1016/j.scitotenv.2018.06.349

Sharma A (2019) Drought management policy of india: an overview. Disaster Adv 12(11):51-62

Sharma A, Sen S (2021) 'Impact of drought on economy: a district level analysis of Madhya Pradesh, India', Journal of Environmental Planning and Management. Routledge 64(6):1021-1043. https://doi.org/10.1080/09640568.2020.1797651

Singh NP, Anand B, Khan MA (2018) 'Micro-level perception to climate change and adaptation issues: a prelude to mainstreaming climate adaptation into developmental landscape in India', Natural Hazards. Springer, Netherlands 92(3):1287-1304. https://doi.org/ 10.1007/s11069-018-3250-y

Singh P, Agrawal G (2020) Development, present status and performance analysis of agriculture insurance schemes in India: review of evidence. Int J Soc Econ 47(4):461-481. https://doi.org/10. 1108/IJSE-02-2019-0119

Sinha S, Tripathi NK (2016) Assessing the challenges in successful implementation and adoption of crop insurance in Thailand. Sustainability (switzerland). https://doi.org/10.3390/su8121306

Smit B, Skinner MW (2002) Adaptation options in agriculture to climate change: a typology. Mitig Adapt Strat Glob Change 7(1):85114. https://doi.org/10.1023/A:1015862228270

Smith VH (2016) Producer insurance and risk management options for smallholder farmers. World Bank Res Obs. https://doi.org/10. 1093/wbro/lkw002

Stricevic R, Djurovic N, Djurovic Z (2011) Drought classification in Northern Serbia based on SPI and statistical pattern recognition. Meteorol Appl. https://doi.org/10.1002/met.207

Suebpongsang P, Benchaphun E, Cramb R (2020) 'Chapter 2 - Commercialisation of rice farming Thailand, in Northeast', in Cramb, R. (ed.) White Gold - the commercialisation of rice farming in the Lower Mekong Basin. Palgrave Macmillan. https://doi.org/ $10.2307 / 2996870$

Suryanto, Gravitiani E, Daerobi A, Susilowati F (2020) 'Crop insurance as farmers adaptation for climate change risk on agriculture in Surakarta residency-Indonesia', International Journal of Trade and Global Marketshttps://doi.org/10.1504/IJTGM.2020.106771

Swain M (2014) Crop insurance for adaptation to climate change in India. Asia Research Centre (ARC), The London School of Economics \& Political Science

Taylor M (2011) "Freedom from poverty is not for free": rural development and the microfinance crisis in Andhra Pradesh, India. J Agrar Chang 11(4):484-504. https://doi.org/10.1111/j.1471-0366. 2011.00330.x

Tothmihaly A, Ingram V (2019) How can the productivity of Indonesian cocoa farms be increased? Agribusiness 35(3):439-456. https://doi.org/10.1002/agr.21595

UNESCAP and ASEAN (2020) Ready for the dry years - building resilience to drought in South-East Asia Second Edition. Available at: https://www.unescap.org/sites/default/files/publications/Ready for the Dry Years.pdf.

Ward PS, Makhija S (2018) 'New modalities for managing drought risk in rainfed agriculture: evidence from a discrete choice experiment in Odisha. India', World Development. https://doi.org/10.1016/j. worlddev.2018.03.002

Wilhite DA, Hayes, Michael J, Knutson C, Smith KH (2000) 'Planning for drought: moving from crisis to risk management', Journal 
of the Am Water Resour Assoc 36(4) 697-710https://doi.org/10. 1111/j.1752-1688.2000.tb04299.x

Wilhite DA, Sivakumar MVK, Pulwarty R (2013) (2014) 'Managing drought risk in a changing climate: the role of national drought policy.' Weather Clim Extremes Elsevier 3:4-13. https://doi.org/ 10.1016/j.wace.2014.01.002

Williams NE, Carrico A (2017) 'Examining adaptations to water stress among farming households in Sri Lanka's dry zone', Ambio. Springer, Netherlands 46(5):532-542. https://doi.org/10.1007/ s13280-017-0904-z

Wright WJ (2005) Agricultural drought policy and practices in Australia, natural disasters and extreme events in agriculture: impacts and mitigation. https://doi.org/10.1007/3-540-28307-2_12
Zhou, C-S, Shao-Yu W (2013) 'Econometric analysis on factors influencing agricultural production output', in International Conference on Management Science and Engineering - Annual Conference Proceedings. https://doi.org/10.1109/ICMSE.2013.6586304.

Publisher's Note Springer Nature remains neutral with regard to jurisdictional claims in published maps and institutional affiliations. 